\title{
Regarding the influence of sex and aging on dry eye disease
}

This article was published in the following Dove Press journal:

Clinical Interventions in Aging

II September 2017

Number of times this article has been viewed

\section{Sang Beom Han}

Department of Ophthalmology, Kangwon National University Hospital, Kangwon National University Graduate School of Medicine, Chuncheon, Republic of Korea
Correspondence: Sang Beom Han Department of Ophthalmology, Kangwon National University Hospital, 156 Baengnyeong-ro, Chuncheon 200-722,

Kangwon, Republic of Korea

Tel +82 332589210

Fax +82 332582296

Email m.sangbeom.han@gmail.com

\section{Dear editor}

I read with great interest the article by Ahn et $\mathrm{al}^{1}$ entitled "Sex differences in the effect of aging on dry eye disease", in which the authors revealed the sex differences in the effect of aging on dry eye disease (DED) in Korean adult population. They also showed the differences in patterns of DED following ocular surgery according to sex. ${ }^{1}$ The large population-based cross-sectional study was undoubtfully well designed and conducted, and suggests that matching of age and sex is recommended in further researches on DED. ${ }^{1}$

However, I would like to point out that there exist controversies regarding the effect of aging and sex on DED. Our previous study showed that age had no significant association with the prevalence of DED in adults of 65 years or older, while female sex was significantly related to increased prevalence of DED. ${ }^{2}$ By contrast, studies in the US demonstrated that prevalence of DED increased with aging both in male and female populations. ${ }^{3,4}$ Moreover, there are differences in pathophysiology of DED according to age. Although dysfunction of lacrimal and meibomian glands may play an important role in the pathogenesis of DED in the elderly, DED associated with visual display terminal use or contact lens wear is more common in young and middleaged patients. ${ }^{5}$ Therefore, I believe these differences in the pathogenesis should be considered in the evaluation of the effects of sex and aging on DED.

Considering that sex hormones may account for the sex-related differences in the associations between DED and aging, ${ }^{1}$ I would also like to point out that the evaluation of the association between age of menopause and DED could be helpful for elucidation of the sex-related differences. In addition, although the authors did include rheumatic arthritis and depression in the analyses, inclusion of other rheumatic diseases including Sjögren syndrome and psychologic conditions including stress, anxiety or sleep disorder would also be informative.

I believe consideration of these factors might be helpful for the authors to perform further researches regarding the influence of sex and aging on DED.

\section{Disclosure}

The author reports no conflicts of interest in this communication.

\section{References}

1. Ahn JH, Choi YH, Paik HJ, Kim MK, Wee WR, Kim DH. Sex differences in the effect of aging on dry eye disease. Clin Interv Aging. 2017;12:1331-1338.

2. Han SB, Hyon JY, Woo SJ, Lee JJ, Kim TH, Kim KW. Prevalence of dry eye disease in an elderly Korean population. Arch Ophthalmol. 2011;129(5):633-638 
3. Schaumberg DA, Dana R, Buring JE, Sullivan DA. Prevalence of dry eye disease among US men: estimates from the Physicians' Health Studies. Arch Ophthalmol. 2009;127(6):763-768.

4. Schaumberg DA, Sullivan DA, Buring JE, Dana MR. Prevalence of dry eye syndrome among US women. Am J Ophthalmol. 2003;136(2): 318-326.
5. Uchino M, Schaumberg DA, Dogru M, et al. Prevalence of dry eye disease among Japanese visual display terminal users. Ophthalmology. 2008; 115(11):1982-1988. 


\section{Authors' reply \\ Jong Ho Ahn' \\ Yoon-Hyeong Choi ${ }^{2}$ \\ Hae Jung Paik' \\ Mee Kum Kim ${ }^{3}$ \\ Won Ryang Wee ${ }^{3}$ \\ Dong Hyun Kim'}

'Department of Ophthalmology, Gachon University Gil Medical Center, ${ }^{2}$ Department of Preventive Medicine, Gachon University College of Medicine, Incheon, ${ }^{3}$ Department of Ophthalmology, Seoul National University College of Medicine, Seoul, Republic of Korea

Correspondence: Dong Hyun Kim

Department of Ophthalmology, Gachon University Gil Medical Center,

I I 98, Guwol-dong, Namdong-Gu, Incheon 21565, Republic of Korea

Tel +82324603364

Fax +82 324603358

Email amidfree@gmail.com

\section{Dear editor}

We thank the author for taking a profound interest in our study. We agree with the author's opinion that there were a few controversial points in this study, and several factors such as psychologic condition, sleep disorder, and visual display terminal use should be considered. However, to the best of our knowledge, there was no report showing a difference in aging effects on DED according to sex, and many epidemiologic studies ${ }^{1-3}$ including the author's study, did not consider previous ocular surgery history which could be a major risk factor of DED. Our study considered previous ocular surgery and other significant factors in DED, and showed consistent differences in aging effects on DED between men and women from large-scale population and several statistical methods. In that sense, our study can be meaningful. We do not try to say that aging in men may be more related with DED than in women. The focus of this study is that there may be distinct sex differences in the effect of aging on DED, and age- and sex matching are very important in clinical studies about DED.

\section{Disclosure}

No author has any proprietary or conflicting interest in this communication.

\section{References}

1. Han SB, Hyon JY, Woo SJ, Lee JJ, Kim TH, Kim KW. Prevalence of dry eye disease in an elderly Korean population. Arch Ophthalmol. 2011; 129(5):633-638.

2. Schaumberg DA, Dana R, Buring JE, Sullivan DA. Prevalence of dry eye disease among US men: estimates from the Physicians' Health Studies. Arch Ophthalmol. 2009;127(6):763-768.

3. Schaumberg DA, Sullivan DA, Buring JE, Dana MR. Prevalence of dry eye syndrome among US women. Am J Ophthalmol. 2003;136(2): 318-326.

Dove Medical Press encourages responsible, free and frank academic debate. The content of the Clinical Interventions in Aging 'letters to the editor' section does not necessarily represent the views of Dove Medical Press, its officers, agents, employees, related entities or the Clinical Interventions in Aging editors. While all reasonable steps have been taken to confirm the content of each letter, Dove Medical Press accepts no liability in respect of the content of any letter, nor is it responsible for the content and accuracy of any letter to the editor.

\section{Publish your work in this journal}

Clinical Interventions in Aging is an international, peer-reviewed journal focusing on evidence-based reports on the value or lack thereof of treatments intended to prevent or delay the onset of maladaptive correlates of aging in human beings. This journal is indexed on PubMed Central, MedLine,
CAS, Scopus and the Elsevier Bibliographic databases. The manuscript management system is completely online and includes a very quick and fair peer-review system, which is all easy to use. Visit http://www.dovepress. com/testimonials.php to read real quotes from published authors. 